\title{
Dividends, Share Repurchases, and Substitution Hypothesis among UK Companies
}

\author{
XING XIE ${ }^{1, a}$ \\ ${ }^{1}$ Changzhou Vocational Institute of Mechatronic Technology, Department of Economics and \\ Management, Changzhou, Jiangsu, China, 213000 \\ a jenniferxiexing2009@hotmail.com
}

Key Words: Payout policy, Substitution Hypothesis, Share Repurchases, Dividends

\begin{abstract}
This paper uses the UK companies as initial sample to investigate the payout policy and the substitution hypothesis between dividends and share repurchases in the UK. We find the payout choice of a firm is determined by its characteristics. A Lintner's model is used to prove the absence of substitution relationship between dividends and share repurchases in the UK.
\end{abstract}

\section{Introduction}

To date, share repurchases have become a global trend. Grullon and Michaely (2004) pointed out that cash flow spent on share repurchases exceeds dividend payments among US industrial corporations[1]. Similarly, share repurchases have an increasing tendency in the UK (Oswald and Young, 2004) and Canada (M. Kooli and L'Her, 2010)[2,3]. This paper will use the UK companies as initial sample to investigate the payout policy and the substitution hypothesis between dividends and share repurchases in the UK.

This paper is organised as follows: Section 2 we use the multivariate probit model to analyze the factor that might affect the choice between repurchases and dividends. Our result indicates that the choice between dividends and share repurchases is affected by the characteristics of a firm. Section 3 investigates whether the substitution between dividends and share repurchases exists in the UK market. We use cross-sectional and time series data to validate the Grullon and Michaely (2002) test[4]. We find that the substation between dividends and share repurchases in the UK does not exist.

\section{The Choice between Dividends and Share Repurchases}

Model and Data. Here we follow Kooli and L'Her (2010) in using the multinomial probit (MNP) regression model to analyze which firm characteristics predict payout policy[3]. Firstly, we considered a utility function of choice $j, j=1, \ldots, J$ :

$$
U_{i, j}=X_{i} \beta_{j}+\varepsilon_{i j}
$$

Where $U_{i, j}$ refers to the utility company $i$ obtained if the $j$ th choice is chosen. $X_{i}$ is a $1 \times K$ vector that contains the observed $k$ independent variables for the ith decision-maker. $\beta_{j}$ is the associated coefficient vector for choice $j$. The error terms $\varepsilon_{i 1}, \ldots, \varepsilon_{i j}$ are independently and identically distributed. The decision-maker selects the $k$ th choice when $U_{i k}>U_{i j}$, for $j \neq k$. The probability of alternative $k$ being chosen is

$$
\operatorname{Prob}(i \text { choose } k)=\operatorname{Prob}\left(U_{i k}>U_{i j}, j \neq k\right)=\operatorname{Prob}\left(\varepsilon_{i k}-\varepsilon_{i j}>X_{i}\left(\beta_{j}-\beta_{k}\right), j \neq k\right)
$$

Thus, by determining the probabilities from the multivariate normal distribution, we can evaluate 
the log-likelihood function and estimate the coefficient vectors $\beta_{j}$.

In this paper, the probability of distributing cash from dividends payment or share repurchases depends on certain firm characteristics. Following a similar procedure in Kooli and L'Her (2010), we only consider four alternative methods of payout policy (no payout, dividends only, repurchase only, dividends and repurchase) because we focus on choosing between dividends and repurchase. In this MNP model, the value of dependent variable can be 1,2,3,or 4, representing no payout, dividends only, repurchase only, and dividends plus repurchases, respectively.

For the explanatory factors, we consider the different payout policies may be correlated with the market value, operating income, income stability, and the leverage level of the firm. We likewise investigated whether the financial crisis from 2007 to 2010 influenced the payout policy of firms, and tested any such influence using factor dummy variables in the model.

We set $X_{i}=\left[C, \ln (M V)_{i}, R O A_{i}, \sigma(R O A)_{i}, M B_{i}, D 20 X X_{i}\right]$ as the explanatory variable vector. The independent variables are defined by:

$\ln (M V)$ is the logarithm of the market value of common stock.

$R O A$ is the operating income before depreciation and amortization scaled by the book value of the total assets.

$\sigma(R O A)$ is the standard deviation of $R O A$ during the three years surrounding the firm-year observation.

$\mathrm{MB}$ is equal to the book value of the total assets plus the market value of equity less the book value of equity scaled by the book value of the total assets.

$D 20 X X_{i}=1$ if the $i$ th observation occurs in the year $20 X X$; and $=0$ otherwise. The four dummies are D2007, D2008, D2009, and D2010.

$C$ is the constant value.

The dataset included 1100 firm-year observations on 150 firms from 2003 to 2011. To obtain a fair reflection of the behaviour of the largest UK firms, we choose the UK-domiciled firms that belonged to FTSE350, which is the largest 350 companies by capitalisation on the London stock exchange, from 2002 to 2011 as our initial sample.

MNP Estimation Results. Table 1 indicates the MNP estimation results. The different models indicate varied comparisons among the four alternative payout methods. In this study, we verified which firm characteristics lead decision-makers to choose method A relative to B. This was denoted as Mprobit $\left(P_{A} / P_{B}\right)$ in the table. In the MNP regression, alternative $\mathrm{B}$ is set as the base outcome. Table 1 also depicts the obtained coefficients and corresponding p-values.

Table 1 Multinomial Probit Regression Estimation Results

\begin{tabular}{|c|c|c|c|c|c|c|c|c|}
\hline \multirow{2}{*}{$\begin{array}{l}\text { Independe } \\
\text { nt } \\
\text { Variables }\end{array}$} & \multicolumn{2}{|c|}{$\begin{array}{l}\text { Category } 1 \\
\text { orobit }\left(P_{D V} / P_{N P}\right)\end{array}$} & \multicolumn{2}{|c|}{$\begin{array}{c}\text { Category } 2 \\
\text { Mprobit }\left(P_{R E P O} / P_{N P}\right)\end{array}$} & \multicolumn{2}{|c|}{$\begin{array}{c}\text { Category } 3 \\
\text { Mprobit }\left(P_{D I V} / P_{R E P O}\right)\end{array}$} & \multicolumn{2}{|c|}{$\begin{array}{cc}\text { Category } & 4 \\
\text { Mprobit }\left(P_{\text {ВОTH }} / P_{R E P O}\right)\end{array}$} \\
\hline & Coefficient & $p$-value & Coefficient & $p$-value & Coeff & $p$-value & $n t$ & $p$-value \\
\hline $\operatorname{Ln}(M V)$ & $323 * *$ & 0.000 & $0.291 * *$ & 0.000 & 0.032 & 0.624 & 0.210 & 0.001 \\
\hline$R O A$ & $6.865^{* *}$ & 0.000 & 0.871 & 0.535 & $5.994 * *$ & 0.000 & $6.008^{* *}$ & 0.000 \\
\hline$\sigma(R O A)$ & -3.418 & 0.104 & -1.779 & 0.055 & -1.640 & 0.264 & -1.654 & 0.288 \\
\hline$M B$ & $-0.439 * *$ & 0.000 & -0.043 & 0.535 & $-0.395^{* *}$ & 0.000 & $-0.263^{*}$ & 0.014 \\
\hline D2007 & -0.292 & 0.258 & 0.117 & 0.795 & -0.409 & 0.332 & 0.320 & 0.448 \\
\hline D2008 & -0.243 & 0.330 & -0.034 & 0.948 & -0.208 & 0.687 & 0.609 & 0.239 \\
\hline D2009 & -0.317 & 0.165 & 0.272 & 0.447 & -0.590 & 0.074 & $-0.720 *$ & 0.032 \\
\hline D2010 & -0.291 & 0.229 & 0.174 & 0.644 & -0.465 & 0.174 & -0.566 & 0.103 \\
\hline Intercept & -0.891 & 0.051 & $-3.031 * *$ & 0.000 & $2.140 * *$ & 0.000 & 0.164 & 0.767 \\
\hline
\end{tabular}

$* *$, * are significantly different from zero at $1 \%$ and $5 \%$ levels,

Category 1 compares the payout policy between dividends only and no payout. The results indicate that larger firms and firms with higher operating incomes are more likely to pay dividends. 
In addition, the firms with high leverage levels are less likely to pay dividends. These results are consistent with our prediction and that of Lintner's (1956) model. In the Canada study (Kooli and L'Her, 2010), the MV, ROA and MB are significantly related to the decision of choosing dividends only relative to no payout, and this is similar to our result.

Category 2 compares the choice between repurchases only and no payout. The results show that only firm size influences the possibility of repurchases relative to no payout, which indicates that large firms are more likely to buy back their shares. In Canada, the decision to repurchase relative to no payout is affected by ROA and MB, which is different from our findings (Kooli and L'Her, 2010).

Firm size is no longer significant when firms choose payouts between dividends and repurchases, as shown in Category 3, which indicates that small and large UK firms are similar when choosing share repurchase or dividend payout to shareholders. These firms are more concerned about operating income and liabilities. The positive coefficients of $R O A$ and $M B$ indicate that UK firms with high income are more likely to pay dividends. However, among the 1100 firm-year observations, only 18 indicate that firms repurchased during the year.

Comparing the choices between both dividend payouts with repurchase shares and sole repurchase reveals that the $\operatorname{Ln}(M V), R O A$, and $M B$ coefficients are significant at $95 \%$ confidence level. Large firms with high income and fewer liabilities tend to pay out with both dividends and repurchases.

The factor that deviated from our expectations is the influence of the financial crisis. Apart from the 2009 year-dummy variable in Category 4, all dummy variables are insignificant at 95\% confidence level. This result shows the financial crisis from 2007 to 2010 does not influenced the payout policy of firms.

\section{Test of Substitution Hypothesis}

Model and Data. Apart from learning which firm characteristics influence the payout choice of UK companies, we are similarly interested in whether share repurchase is considered a substitute of dividends payment in the UK.

Lintner (1956) as well as Grullon and Michaely (2002)[4,5] reported that the firm's dividends policy is relative to their targeted payout ratio and the adjustment speed of current dividends. The expected dividends could be estimated based on a firm's previous dividends-payment behaviours. A comparison between the expected and actual dividends payments could determine whether the firms' dividends policies have changed. In other words, if the firms substitute dividends payment with share repurchases, the actual dividends would be less than the expected dividends payment, and the gap would widen as repurchases increase. For a mathematical description, "If firms are substituting repurchases for dividends, then we should find a negative correlation between the dividends forecast error (actual minus expected) and share repurchase activity." (Grullon and Michaely, 2002)[4]. Alternatively, a non-negative correlation between the forecast error and share repurchase indicates that share repurchases and dividends payments may have relationships other than substitution, such as complementary or independent interactions.

Following the procedure and model described in Grullon and Michaely (2002), we chose the preforecast period from 2002 to 2011. The dividend forecast error is as follows:

$$
\operatorname{ERROR}_{t, i}=\left[\Delta D I V_{t, i}-\left(\beta_{1, i}+\beta_{2, i} E A R N_{t, i}+\beta_{3, i} D I V_{t-1, i}\right)\right] / M V_{t-1, i}
$$

Where the $\triangle D I V_{t, i}$ is the actual change of dividends payment of company $i$ in year $t$ and $E A R N_{t, i}$ is the total earnings before extraordinary items of company $i$ in year $t$, we use EBIT as the earnings in our model. $M V_{t-1, i}$ is the market value of equity for company $i$ in year $t-1$. From Lintner's (1956) model, the coefficients $\beta_{2, i}$ and $\beta_{3, i}$ are the estimated parameters and then the constant term $\beta_{1, i}$ is the estimated constant over the pre-forecast period. Following Grullon and Michaely (2002), we scale 
all the variables in Lintner's model by the market value of firms when estimating and calculating the errors for reducing the effect of heteroskedasticity and robust our error estimation.

The sample selection included companies that continuously paid dividends over several years during the pre-forecast period so that the Lintner's model could be estimated. In our procedure, the sample firms continuously paid dividends for at least seven years from 2002 to 2011. Similarly, we reduced outlier influence by eliminating extreme observations in which the absolute value of the forecast error is greater than $5 \%$.

The relationship between the forecast error and share repurchase could be determined by defining the repurchase yield (RYIELD) as the total expenditure on share repurchase at time $t$ scaled by the market value of equity at time $t-1$. We also define the dividend yield (DYIELD) as the total expenditure on dividends at time $t$ scaled by the market value of equity at time $t-1$ for further analysis. The scaling procedure confined all samples at the same level, enabling the comparison with forecast errors. We truncated RYIELD and DYIELD at the $99^{\text {th }}$ percentile to reduce outlier influence.

Result. We first ran the regression equations of Lintner's model for each firm, and obtained the estimated coefficients and adjusted $R^{2}$. The average coefficients of earnings and lagged-dividends yield were determined as 0.021 and -0.427 , respectively. The positive earnings coefficient and negative lagged-dividends yield coefficient are consistent with the findings of Grullon and Michaely (2002). The average adjusted $R^{2}$ is $38.8 \%$.

Table 2 Relation between Dividend Forecast Errors and Share Repurchase Yield

\begin{tabular}{|c|c|c|c|c|c|c|c|}
\hline \multirow{3}{*}{$\begin{array}{c}\text { Preforecast } \\
\text { Period }\end{array}$} & \multirow{3}{*}{$\begin{array}{l}\text { Entire } \\
\text { Smple }\end{array}$} & \multicolumn{6}{|c|}{ Groups Ranked by Share Repurchase Yield } \\
\hline & & 1 & & & & 5 & \\
\hline & & (Low) & 2 & 3 & 4 & (High) & $(5-1)$ \\
\hline \multicolumn{8}{|l|}{$2003-2011$} \\
\hline \multicolumn{8}{|l|}{ ERROR } \\
\hline Mean & $-0.104 \%$ & $-0.138 \%$ & $-0.045 \%$ & $-0.036 \%$ & $-0.149 \%$ & $-0.166 \%$ & $-0.028 \%$ \\
\hline Median & $-0.021 \%$ & $-0.028 \%$ & $-0.018 \%$ & $-0.010 \%$ & $-0.005 \%$ & $-0.030 \%$ & $-0.002 \%$ \\
\hline Std.Dev & $0.844 \%$ & $0.929 \%$ & $0.787 \%$ & $0.444 \%$ & $1.003 \%$ & $0.893 \%$ & $0.893 \%$ \\
\hline $\mathrm{N}$ & 775 & 407 & 174 & 116 & 40 & 38 & --- \\
\hline \multicolumn{8}{|l|}{ RYIELD } \\
\hline Mean & $0.838 \%$ & 0 & $0.242 \%$ & $1.528 \% *$ & $3.922 \% * *$ & $7.180 \% * *$ & $7.180 \% * *$ \\
\hline Median & 0 & 0 & $0.205 \%$ & $1.389 \% *$ & $3.871 \% * *$ & $6.739 \% * *$ & $6.739 \% * *$ \\
\hline Std.Dev & $1.790 \%$ & 0 & $0.179 \%$ & $0.673 \%$ & $0.574 \%$ & $1.626 \%$ & $1.626 \%$ \\
\hline $\mathrm{N}$ & 775 & 407 & 174 & 116 & 40 & 38 & --- \\
\hline \multicolumn{8}{|l|}{ DYIELD } \\
\hline Mean & $3.463 \% *$ & $3.506 \% *$ & $3.231 \% *$ & $3.330 \% *$ & $3.577 \% * *$ & $4.348 \% *$ & $0.842 \%$ \\
\hline Median & $3.218 \%$ & $3.221 \%$ & $3.074 \%$ & $3.173 \% *$ & $3.612 \% * *$ & $3.810 \%$ & $0.589 \%$ \\
\hline Std.Dev & $1.664 \%$ & $1.681 \%$ & $1.580 \%$ & $1.541 \%$ & $1.362 \%$ & $2.170 \%$ & $2.170 \%$ \\
\hline $\mathrm{N}$ & 775 & 407 & 174 & 116 & 40 & 38 & --- \\
\hline
\end{tabular}

We calculated the ERROR, DYIELD, and RYIELD by the definition. The RYIELD is not uniformly distributed. Thus, we divided the ERROR, DYIELD, and RYIELD into groups based on the RYIELD rank. RYIELD was ranked from low to high by percentiles of 50, 75, 90, 95, and the highest, 5. Table 2 presents the results.

Observations in groups 3 to 5 depict an apparent negative relationship between ERROR and RYIELD. However, when testing the hypothesis that the ERROR is equal to zero, none of the data (with the means of ERROR in different groups or the mean of the entire sample) could be rejected at 95\% confidence level. This result suggests that the means of different groups of ERROR are approximately equal to zero, meaning that no such forecast errors occur. In other words, UK firms pay the same dividends as expected and retain their past dividends policies. Furthermore, zero forecast errors means that forecast errors and share repurchases are not related, indicating an 
independent relationship rather than substitution between dividends and share repurchases in UK companies. The same conclusion could be obtained by the analysis of the different RYIELD groups and their corresponding DYIELD. In the four groups, excluding group 1, the firms with a high dividends payout ratio tend to use a significant portion of funds to buy back their shares. However, the difference between the DYIELD mean in the largest group and that in the smallest group is insignificant at 95\% confidence level. Thus, firms with the highest share repurchase yield paid a portion of dividends similar to that of firms that did not repurchase shares. Again, the result indicates that the firms did not substitute dividends payments with repurchases during this period.

This situation can be explained by the fact that smaller repurchase payout ratio combined with relatively stable dividend payout ratio makes substitution less possible to happen in the UK. This is mainly caused by: 1) the repurchase regulation of the UK discourages the undervalued share repurchases (Ran and Vermaelen 2002)[6]. As we all know, most firms repurchase their own shares only when they think their shares are undervalued. The regulation can also influence the repurchase from the signaling aspect. 2) The tax in the UK also makes share repurchases less attractive. As Ran and Vermaelen (2002) say, "unlike in the United States, pension funds have had a clear tax preference for dividend payments, at least until the UK government abolished the imputation system in July 1997'[6]. The preference for dividend payments result in high dividends and low share repurchase in UK.

\section{Conclusions}

We used the multinomial probit model to investigated the factors that affect the payout choice of dividend and repurchase. The result shows that he decision to repurchase is positively related with earnings and negatively related with the leverage level of the firm.

We also used Lintner's model to test whether a substitution relationship occurs between dividends payments and share repurchases. Our results indicate that no such relationship exists in UK firms, consistent with the findings of Oswald and Young (2007)[7]. And we believe his situation might be caused by the tax and regulations of UK. Both the tax and regulations in UK discourage share repurchases, which makes the firm do not substitute the share repurchases for dividends.

\section{References}

[1] Grullon, G. and R. Michaely (2004), “The information content of share repurchase programs”, Journal of Finance 59, 651-680.

[2] Oswald, D. and S. Young (2004), "What role taxes and regulation? A second look at open market share buy back activity in the UK”, Journal of Business Financial and Accounting 31, 257-292.

[3] M. Kooli, and J. F. L’Her (2010), “Dividends versus Share Repurchases Evidence from Canada: 1985-2003”, The Financial Review 45, 57-81.

[4] Grullon, G. and R. Michaely (2002), "Dividends, share repurchases and the substitution hypothesis”, Journal of Finance 57, 1649-1684.

[5] Lintner, J., (1956), “Distribution of incomes of corporations among dividends, retained earnings, and taxes”, American Economics Review 46, 97-113.

[6] Ran, P. R. and T. Vermaelen (2002), "Regulation, Taxes, and Share Repurchases in the United Kingdom.” Journal of Business 75(2): 245-282.

[7] Oswald, D. and S. Young (2007), "Share requisitions, surplus cash, and agency problems" Journal of Banking \& Finance 32(2008) 795-806.

谢星, 女, 汉族, (1988.9-) 江苏溧阳人, 硕士研究生, 助教, 常州机电职业技术学院, 研究方向：经济学数 据分析。 
通讯地址：常州市武进区莱蒙城官邸别墅区T9栋06号, 邮编：213000, 联系电话： 13627486299 谢星 